\title{
Study on genetically modified food in Slovenia
}

\author{
P. $\mathrm{KOSI}^{1, \mathrm{a}}, \mathrm{J} . \mathrm{WANG}^{1, \mathrm{a}^{*}}$ \\ ${ }^{1}$ Department of Environmental Management and Sustainable Development, Tongji Institute of \\ Environment and Sustainable Development, Shanghai, China. \\ ${ }^{a}$ *Corresponding Author: wangjuan@tongji.edu.cn
}

Keywords: Genetically modified food, Slovenia

Abstract:Biotechnology, one of the fastest developments in the century, is creating the diversity of opinions and one of the greatest debates emerged in the field of genetically modified (GM) food. Even though the innovation was developed to tackle the world hunger it still represents unknown concept that can cause potential risk on the environment and human health. GM food has found itself in a social context and affected many other spheres: economical, political, social, cultural and ethical. Some countries welcomed the innovation, some started to protect themselves from it. In the following article Slovenia will be presented as an example of how social, economic, geographical and public constrains prevented to grow genetically modified corn.

\section{Definition and Concerns about Genetically Modified Food}

In 1946 genetic scientists, firstly discovered that DNA could be transferred between organisms. Hence the modern biotechnology started its expansion and genetic engineering became the creator of a new invention - genetic manipulations. It was used in many spheres such as medicine or pharmacy, and in time, with the growing population and scarcity of natural resources, it became an important element in agriculture, environment and food industry. The official definition of Genetically Modified Food as provided by World Trade Organization (WTO) states that: "Genetically modified foods are foods derived from organisms whose genetic material (DNA) has been modified in a way that does not occur naturally, e.g. through the introduction of a gene from a different organism." [WTO, 2015]

The first genetically modified plant was produced in 1983 in China, using an antibiotic-resistant tobacco plant. Now, 40 years after, biotechnology offers three most popular genetic modifications of the crops /1/ with resistance to herbicides, /2/ with resistance to pests and /3/ with resistance to viruses. A lot of the genetically modified food products are already available on the market including cotton, soybean, canola, potatoes, eggplant, strawberries, corn, tomatoes, lettuce, cantaloupe, carrots etc. Genetically modified crops have been legalized in 28 countries, among which the leading producers are USA, Brazil, Argentina, India, Canada and China.

\section{Socio - economic concerns about Genetically modified food}

It can be assumed that the tools, which are producing the genetically modified food, are holding the potential to tackle the adaptation to environmental conditions, and to reach all the nutrition and dietary needs to solve world famine. But in praxis even though the greatest agricultural genetic diversity is found in the tropical zones, yet the tools of modern technology are mostly owned in the tempe- 
rate zones. Private corporations and research institutions are failing in making arrangements to share genetic engineering technology with responsible scientists for alleviating hunger in developing countries. Moreover, the technology is now held under strict patents and licensing agreements.

There is also a concern about the possibility that genetic "pollution" will cause great damages to human health. Until now numerous legislations were created to protect the uncertainty people are facing with the food. One problem with this view is that determining food safety is not simple: "safe" implies a value judgment that potential hazards have been adequately analyzed and that any remaining risks are "acceptable". One approach, which is being used in assessing the risks of GMO, derives from the concept of substantial equivalence. It acknowledges that the goal of the assessment is not to establish absolute safety but to consider whether or not the GM food is as safe as its traditional counterpart if the counterpart exists. Those areas race a lot of ethical questions, especially regarding the welfare and future generations.

\section{Environmental concerns about Genetically modified food}

As GMOs enter the food fiber and supply chain they are increasingly released into ecosystems and agro-ecosystems. The flow of genes has to be considered as a possible realistic scenario and therefore suitable agricultural practices have to be established (monitoring, distance isolation, etc.), so that unwanted phenomena can be controlled.

\section{Genetically modified food in Slovenia}

Slovenia, a nation state situated in Central and Southeastern Europe is touching the Alps and bordering the Mediterranean. Of country's total 2.0 million hectares; nearly $40 \%$ is used for agriculture. Of the agricultural area, more than $60 \%$ is permanent pasture and some $30 \%$ is arable. Due to corn month Slovenian farmers were facing huge loses of corn in 2013. They were offered an alternative solution with genetically modified corn MON810 with combined resistance to insects and herbicides. However four main obstacles prevented farmers to use the alternative.

Even though farmers faced huge corn loses the economical losses were controlled. Moreover, if the farmers would decide to grow corn MON810 they would have to wait a long time to get all the necessary allowances from the government. The second biggest obstacles presented Slovenian parted farmland. Slovenia is one of the countries that have the smallest farmland surface area per capita in Europe (0,86 hectares). The small estates and farms with little number of field crops are much more susceptible for unwanted pollination. With additional limitation of the 600-meter safety belt, it is impossible to grow genetically modified corn without the impact on environment. Public opinion and its negative position towards genetically modified food created a third powerful constrain for farmers. They could potentially loose their profits since the demand for genetically modified products among consumers in Slovenia is too small. Forth obstacle turned out to be a new opportunity for Slovenian agriculture - a trend towards organic farming and GMO - free zones. Slovenia has allocated 12,3 Million USD to supporting various measures including organic agriculture and integrated pest management (IPM) for fruit, vine and vegetable production. As from 2015 due to negative European public view on GMO, the majority of European Union countries banned the genetically modified food from the market entirely. 


\section{Conclusion}

Genetic modification is the fastest technological development among the natural sciences in last decade. The innovation is seen as a potential solution to tackle world famine and the increasing demand of food in the future. Even though genetic modification is accepted in different fields (pharmaceutics, medicine) it represents the most intensive discussion on the field of agricultural production of genetically modified food. But as seen in the example of Slovenia there are many obstacles that can enable the growth of genetically modified crops. Lucky till now the country was not faced with any major natural disaster, but due to climate change the situation can change very fast. Farmers will at that time be forced to reconsider the use of genetically modified crops in order to feed the population.

\section{Acknowledgements}

This research was supported by Tongji University and Dr. Wangjuan.

\section{References}

[1] B. Bohinec, Osnove rastlinske biotehnologije in gensko spremenjena hrana, Ljubljana, Slovenia, 2004.

[2] V. Fraser, What's the Moral of the GM Food Story?, Journal of Agricultural and Environmental Ethics, Volume 14, Issue 2, (2001) Kluwer Academic Publisher, pp. 147-159.

[3] FAO, Genetically Modified organisms, consumers, food safety and the environment, FAO Ethic Series 2, FAO Rome, 2001.

[4] B. Javornik, Biotehnologija - kmetijstvo - okolje, In Kmetijstvo in okolje: zbornik posveta, Agriculture Institute of Slovenia (1998), Ljubljana.

[5] C. James, Global status of commercialized biotech/ GM crops, ISAAA Brief No. 42, New York, 2010.

[6] Joint FAO/WHO food Standards programme, Codex Alimentarius Commission, Switzerland, 2006.

[7] I. Kruszewska, Slovenia - A GMO - free zone, Umanotera, Ljubljana, Slovenia, 2001.

[8] Meglic, Soobostoj in ohranjanje biotske raznovrstnosti v kmetijstvu, Kmetijski Institut Slovenije, 2011.

[9] A. Šorgo, J. Ambrozic - Dolinsek, Biotechnology teaching: The relationship among knowledge of, attitudes toward and acceptance of genetically modified organisms (GMOs) among Slovenian teachers, Slovenia, 2009.

[10] J. Zajc, Vloga posameznikovega znanja, virov informacij in zaupanja v druzbene akterje pri oblikovanju stalisc o gensko spremenjenih organismih v Sloveniji, Fakluteta za druzbene vede, Slovenia, 2013.

[11] Information on http://www.unep.org

[12] Information on http://www.wto.org/english/tratop e/sps e/sps agreement cbt e/c8s1p1 e.htm

[13] Information on http://www.cbd.int/convention/

[14] Information on http://ec.europa.eu/food/food/biotechnology/index_en.htm

[15] Information on http://www.organic-europe.net/slovenia.html 